Vol. 11, No. 41, October, 2016, 1265-1274

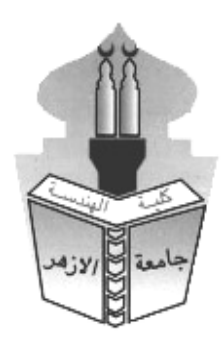

\title{
PASSIVE AND HYBRID TECHNIQUES FOR LOW COST ENERGY EFFECIENT HOUSING IN HOT DRY CLIMATE
}

\author{
Hend Farouh $^{1}$ and. Lubna, E. Amer ${ }^{2}$ \\ ${ }^{1}$ Housing and Building National Research Center, Cairo, Egypt \\ ${ }^{2}$ Cairo University, Giza, Egypt
}

\begin{abstract}
قطاع الإسكان هو المستهلك الرئيسي للكهرباء في مصر حيث انه بستهلك حو الي 42\% من الاستهلاك الكلي للكهرباء. و قد

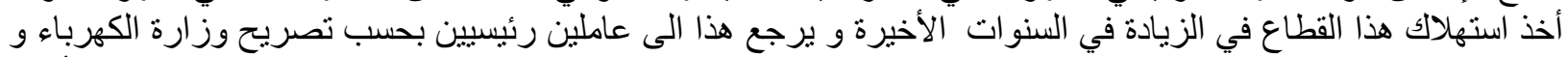

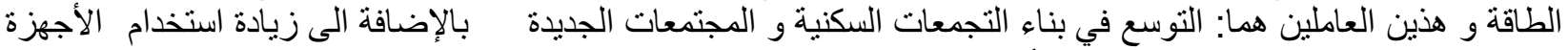

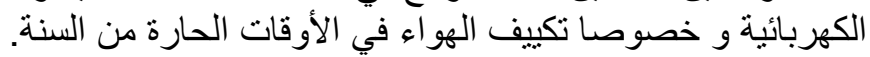

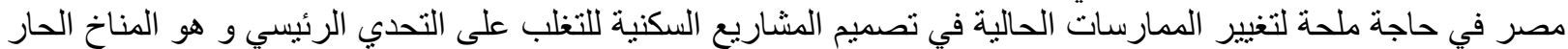

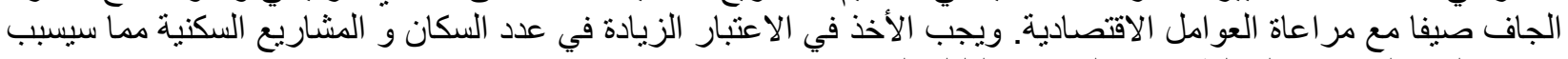
تاثير ا سلبيا على استهلاك الطاقة في السنوات التوات القليلة القادمة. هذا البحث سوف يستكثف الطرق السالبة و الهجين المستخدمة في تصميم المساكن منخفضة التكالبف ذات الكفاءة في استخدام الطاقة في المناخ الحار القاسي.

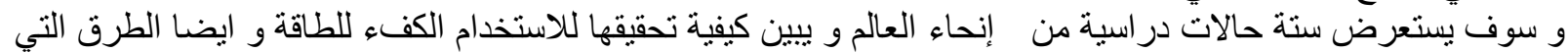

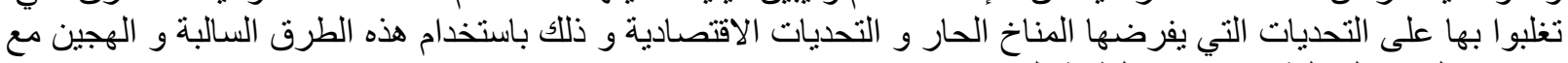

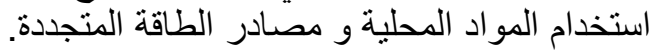
و سوف يوصي البحث ببعض من هذه الأساليب التصميمية المناسبة و الممكن تطبيقها في مصر. الكلمات الدالة: الاسكان منخفض التكاليف - التصميم المستدام - اساليب التصميم المناخي السالبة و الهجين.
\end{abstract}

\begin{abstract}
The main consumer of electricity in Egypt is the residential sector which accounts for $42 \%$ of the total consumption, followed by the industrial sector $(28 \%)$. The consumption of the residential sector has been steadily increasing in the recent years. According to the Ministry of Electricity and Energy, this is due to two factors: the expansion of residential compounds and new communities as well as the use of domestic appliances, air conditioners in particular, during hot weather. Egypt is in a real need to change the "business-as-usual" approach in housing projects to overcome the major challenge of the hot dry climate while respecting the economic factors taking into consideration that increasing population and housing projects will affect negatively the energy demand in the coming few years.

This paper will explore the main passive and hybrid design techniques for low cost energy efficient housing in hot arid climate. It will review six international case studies worldwide showing their energy efficiency practice and their methods to overcome climate and cost challenges using passive and hybrid techniques along with using local materials and renewable energy. The paper will recommend some of these techniques to be implemented in Egypt.
\end{abstract}

\section{Keywords: Low cost housing, sustainable design, passive design and hybrid techniques.}




\section{INTRODUCTION}

Energy Efficient housing is relatively a new concept to Egypt despite the energy efficiency building code for residential buildings has issued by a ministerial decree in 2005. In addition, the definition of low-cost, in a housing sense, depends greatly on the economic capacity of the target group. One concept of affordability may prove too expensive in other instances of country implementation. Mulliner, E. et al. (2013) stated that the traditional way of conceiving and measuring affordability (the ratio of housing costs to income) fails to indicate anything about the quality of the housing or the environment in which the housing is situated, he stated that it is essential that affordability and sustainability issues are tackled simultaneously [1].

There is a real need to establish low cost energy efficient housing projects in Egypt due to the increasing of energy demand. The present energy strategy aims at increasing the share of renewable energy to $20 \%$ of the energy mix by 2020. This target is expected to be met largely by scaling-up of wind power as solar is still costly and the hydro potential is largely utilized. The share of wind power is expected to reach $12 \%$, while the remaining $8 \%$ would come from hydro and solar [2].

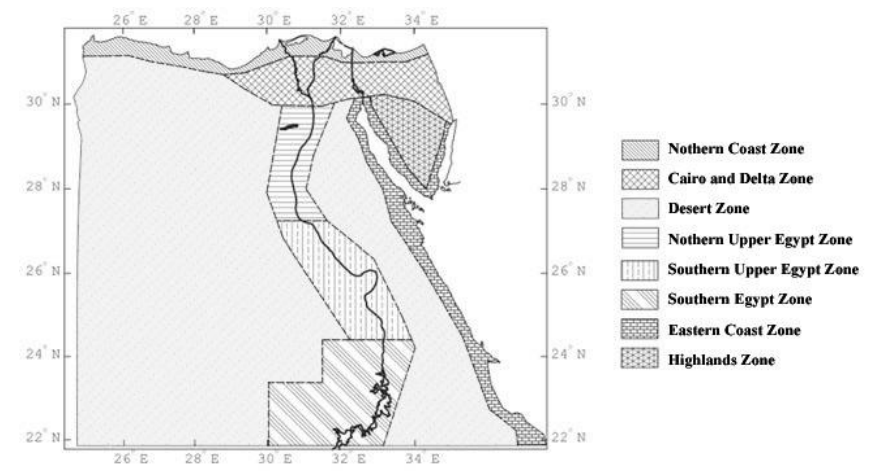

This paper explores passive and hybrid techniques of low cost energy efficient housing in hot arid climate taking into consideration the eight climatic zones as shown in Fig.1 which was divided by The Egyptian Energy Efficiency Building Code, EEBC.

Fig 1:Classification of climatic zones in Egypt

\section{PASSIVE and HYBRID DESIGN TECHNIQUES}

A passive building is a building in which a comfortable interior climate can be maintained without active heating and cooling systems. Passive design is considered as a solution involving the design of properly oriented, shaped, ventilated and shaded buildings suited to the bioclimatic features of the site. In other words, indoor thermal comfort is achieved naturally throughout most of the year. This option requires mostly expert time, and not much investment on materials or equipment [16].

Using simple strategies such as orientation, size of windows openings, shading, and insulation which lead easily to a reduction of the net energy demand of around $30 \%$ and, at the same time indoor comfort is improved [3].

The passive design approach consists of different climate responsive strategies, to avoid heat transfer through the building envelope which mainly focuses on reduce heat gain and provide shade to cool roofs, walls, and windows. The main strategies are [3]:

- Orientation: reduce solar radiation on the building envelope.

- Thermal zoning: allocate functions related to time of use and solar gain.

- Building form and typology: reduce the solar radiation on the building envelope and optimize daylight access.

- Building envelope design (size and location of windows and shading): provide the minimum required daylight access, together with a minimal heat while fulfilling the building codes requirments.

- Ventilation and cooling techniques: use airflow to release heat and humidity.

- Materials selection: to reduce heat transfer to the indoor space.

- Landscaping: provide shade on the building, reducing the heat gain, and to create pleasant outdoor space. 


\subsection{Orientation}

Solar heat gain of a building depends on the sun orientation .buildings are preferably placed on northern slopes to avoid excessive sun exposure, using natural shade. West slopes should be avoided. At higher altitude south exposure might be adequate for reasons of passive heating Valley bottoms(rarely found in Egypt) are additionally heated by reflection of sun radiation from the surrounding slopes.

\subsection{Thermal Zoning}

The location of the building functions should relate to the solar radiation and the users' occupancy patterns. The spaces are positioned in relation to the time of use, and, as required, the need to gain or to be protected from solar radiation. It is recommended that spaces with short term use, such as bathrooms, can be placed on the hot side of the building, the south west. This way they also function as buffer zones to protect other spaces. While the bedrooms are best located on the northeast side, to stay cool and avoid the need for cooling in the evening while gaining sunlight in the morning [3].

\subsection{Building Form and Typology}

Building form refers to the shape, size, and orientation of the building blocks; 'spatial configuration' characterizes how the building blocks are arranged in the given plot of land. Reducing the solar exposure on building surfaces is the first step towards reducing solar heat gains and internal cooling loads. Compact building has a lower surfacevolume ratio, and thus a smaller surface area to absorb solar heat compared to a building with a higher surfacevolume ratio [4].

\subsection{Building Envelope}

Most of the cooling load in the residential buildings originates from solar heat gains and heat transmissions through the envelope (through windows, walls, and roof). Thus, special attention should be paid to reduce solar heat gains and heat transmission through the building envelope. The main building envelope features that influence the cooling thermal energy demand and thermal comfort in a residential unit are: size and location of window openings, shading system for windows, window properties, insulation properties of wall, and insulation properties of roof, color and finish of exterior surfaces (walls and roofs), Natural ventilation, and building air-tightness [4].

The building envelope design should aim at:

- $\quad$ Reduce conductive heat gain and loss

- provision of adequate delighting

- Reduce Solar Heat Gain through:

- Windows: Window to wall ratio (WWR), Solar Heat Gain Coefficient (SHGC), Projection Factor(PF)

- Walls: Building Construction, Wall Insulation : U-Value or Thermal Transmittance, \& Wall Solar Absorptivity ( $\alpha \mathrm{w})$

- Roof: Top Floor: Roof insulation \& roof shading, U-Value

The Energy Efficiency Building Code (EEBC) determined the requirements of the building envelope in the different climatic zone, See table 1 which represents the thermal transmittance U-Value in different climatic zones and table 2 shows the building envelope requirements for a conditioned building Cairo.

Table 1. Thermal Transmittance U-Value in different climatic zones according to EEBC, 2008

\begin{tabular}{|l|c|c|}
\hline Climatic Zones & $\begin{array}{l}\text { Wall } \\
\mathrm{U}_{\mathrm{w}}\left(\mathrm{W} / \mathrm{m}^{2} .{ }^{\circ} \mathrm{C}\right)\end{array}$ & $\begin{array}{l}\text { Roof } \\
\mathrm{U}_{\mathrm{r}}\left(\mathrm{W} / \mathrm{m}^{2} .{ }^{\circ} \mathrm{C}\right)\end{array}$ \\
\hline Great Cairo, Delta \& North of upper Egypt & $1.0 \leq$ & $\leq .50$ \\
\hline North Cost & $1.2 \leq$ & $\leq 0.6$ \\
\hline South of Egypt \& East Coast & $0.8 \leq$ & $\leq 0.4$ \\
\hline Great Cairo, Delta \& North of upper Egypt & $1.0 \leq$ & $\leq .50$ \\
\hline
\end{tabular}

Table 2. The building envelope requirements for a conditioned building Cairo according to EEBC, 2008 


\section{Building Envelope}

Part A : Requirements

\begin{tabular}{|c|c|c|c|c|c|c|c|c|c|c|c|c|c|c|}
\hline & & & & & & & & & & & & \\
\hline 1 & 2 & 3 & 4 & 5 & 6 & 7 & 8 & 9 & 10 & 11 & 12 & 13 & 14 & 15 \\
\hline \multirow{5}{*}{\multicolumn{2}{|c|}{ Orientation }} & \multirow{5}{*}{$\begin{array}{l}\text { External } \\
\text { Surface } \\
\text { Absorptivity } \\
\text { (d) }\end{array}$} & \multicolumn{4}{|c|}{ Required Min R values for Insulation } & \multirow{2}{*}{\multicolumn{3}{|c|}{$\begin{array}{l}\text { Max SHGC Values for } \\
\text { Fenestration }\end{array}$}} & \multirow{2}{*}{\multicolumn{2}{|c|}{ or }} & \multirow{2}{*}{\multicolumn{3}{|c|}{$\begin{array}{l}\text { Min. SGR Values for } \\
\text { Shading Devices }\end{array}$}} \\
\hline & & & \multicolumn{3}{|c|}{ of External walls and roofs } & & & & & & & & & \\
\hline & & & \multirow{3}{*}{\begin{tabular}{|c|} 
Assembly \\
Min Rvalue \\
$\left(\mathrm{m}^{2} \mathrm{C} C \mathrm{~W}\right)$ \\
\end{tabular}} & & \multicolumn{8}{|c|}{ WWR } \\
\hline & & & & \multicolumn{3}{|c|}{$\left(\mathrm{m}^{2 \circ} \mathrm{C} / \mathrm{W}\right)^{\star}$} & \multirow{2}{*}{\multicolumn{4}{|c|}{\begin{tabular}{c|c|c|c|}
$\leq 10 \%$ & $10-<20 \% \mid 20-<0 \%$ & $\geq 30 \%$ \\
\multicolumn{3}{|c|}{ SHGC } \\
\end{tabular}}} & \multirow{2}{*}{$\leq 10 \%$} & \multicolumn{2}{|c|}{\begin{tabular}{|l|l|}
$10-<20 \%$ & $20-<30 \%$ \\
\end{tabular}} & $230 \%$ \\
\hline & & & & 0.4 & 0.6 & 0.8 & & & & & & \multicolumn{2}{|c|}{ SGR } & \\
\hline \multirow[t]{7}{*}{ Roof } & & 0.7 & 2.7 & 2.3 & 2.1 & 1.9 & & & & & & & & \\
\hline & & 0.38 & 0.70 & 0.30 & NR & $\mathrm{NR}$ & \multirow{3}{*}{ NR } & \multirow{3}{*}{ NR } & \multirow{3}{*}{0.71} & \multirow{3}{*}{0.67} & \multirow{3}{*}{ NR } & \multirow{3}{*}{ NR } & \multirow{3}{*}{$60 \%$} & \multirow{3}{*}{$70 \%$} \\
\hline & $\mathrm{N}$ & 0.5 & 0.74 & 0.34 & 0.14 & $\mathrm{NR}$ & & & & & & & & \\
\hline & & 0.7 & 0.82 & 0.42 & 0.22 & $\mathrm{NR}$ & & & & & & & & \\
\hline & \multirow{3}{*}{$\mathrm{NE} / \mathrm{NW}$} & 0.38 & 0.89 & 0.49 & 0.29 & $\mathrm{NR}$ & \multirow{3}{*}{0.65} & \multirow{3}{*}{0.5} & & & & & & \\
\hline & & 0.5 & 1.00 & 0.60 & 0.40 & 0.20 & & & 0.45 & 0.35 & $60 \%$ & $80 \%$ & $90 \%$ & $90 \%$ \\
\hline & & 0.7 & 1.18 & 0.78 & 0.58 & 0.38 & & & & & & & & \\
\hline Walls & & 0.38 & 1.07 & 0.67 & 0.47 & 0.27 & & & & & & & & \\
\hline & $E / w$ & 0.5 & 1.23 & 0.83 & 0.63 & 0.43 & 0.5 & 0.4 & 0.35 & 0.27 & $70 \%$ & $80 \%$ & $90 \%$ & $90 \%$ \\
\hline & & 0.7 & 1.50 & 1.10 & 0.90 & 0.70 & & & & & & & & \\
\hline & & 0.38 & 0.97 & 0.57 & 0.37 & 0.17 & & & & & & & & \\
\hline & SE/SW & 0.5 & 1.10 & 0.70 & 0.50 & 0.30 & 0.5 & 0.4 & 0.35 & 0.27 & $60 \%$ & $80 \%$ & $90 \%$ & $90 \%$ \\
\hline & & 0.7 & 1.32 & 0.92 & 0.72 & 0.52 & & & & & & & & \\
\hline & & 0.38 & 0.82 & 0.42 & 0.22 & 0.02 & & & & & & & & \\
\hline & $S$ & 0.5 & 0.90 & 0.50 & 0.30 & $\mathrm{NR}$ & 0.71 & 0.64 & 0.55 & 0.5 & $60 \%$ & $70 \%$ & $90 \%$ & $90 \%$ \\
\hline & & 0.7 & 1.04 & 0.64 & 0.44 & 0.24 & & & & & & & & \\
\hline
\end{tabular}

There are several techniques for constructing external walls in hot, dry zones. One of the most famous techniques is the use of cavity walls. Heat-reflective membranes were tested to prevent heat flow between the inner and outer wall as shown in Fig. 2.

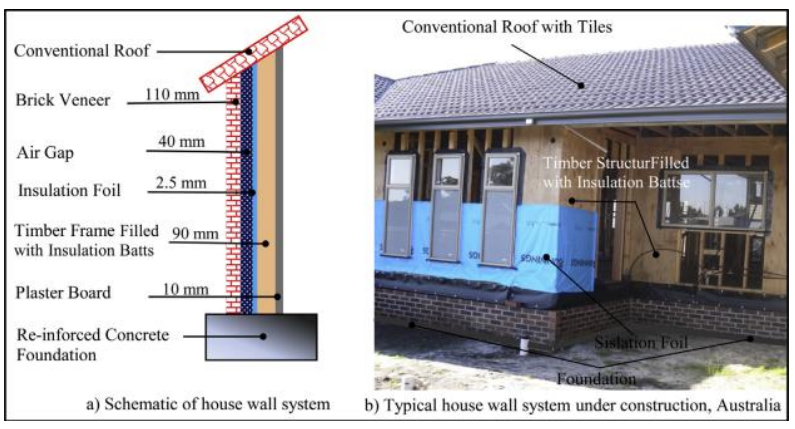

Fig. 2 Energy Efficient Residential House Wall System in Australia

\section{Fig. 2 Energy Efficient Residential House Wall System in Australia}

\subsection{Ventilation and Cooling Techniques}

Passive cooling is based on the interface of the building and its surroundings. Paradoxically, by employing passive cooling techniques into contemporary buildings, architects can eliminate mechanical cooling or even to a small extent decrease the size and cost of the equipment [11].

\subsubsection{Exclude excess solar radiation. (Cooling by effective shading)}

Shading can reduce the temperature between 5 and $10 \mathrm{oC}[12]$.

South-facing windows are easy to shade, because during summer months, when shading is necessary, the angle of the sun is high. However, east and west-facing windows are much more difficult to shade because the sun is much lower in the sky. Shading types as in Fig. 3. are:

a- Shading by Agglomerate of Volumes: Shading resulting from compact volumes

b- Shading on Courtyard

c- Shading by Space in Space Concept. 
d- Shading by Natural Elements (Vertical Plan)

e- Shading by Devices (Movable Insulation):

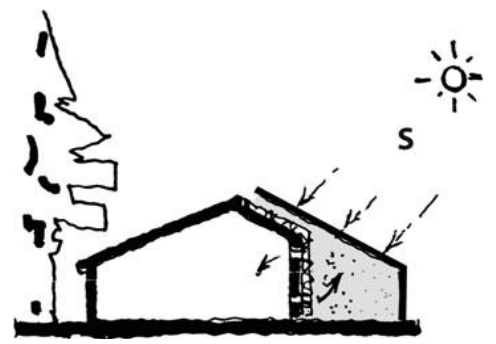

(A) compact volumes

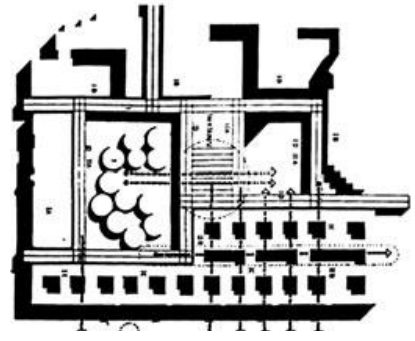

(B) Bioclimatic houses from Iraq

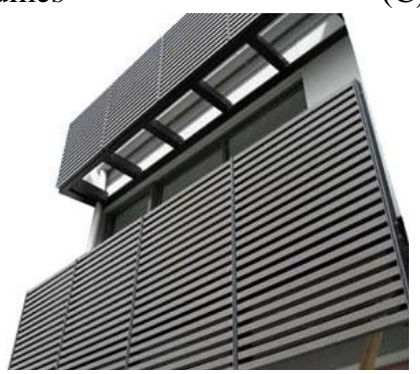

(C) Shading by Space in Space Concept

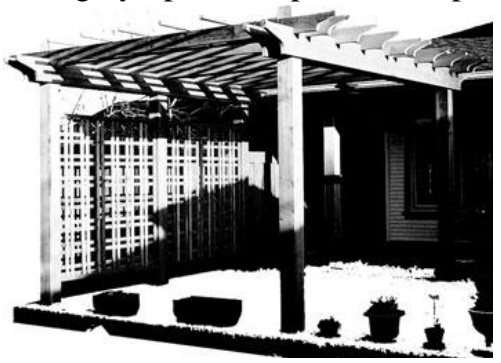

(E) Movable Insulation

Fig. 3. Different Kinds Of Shading

\subsubsection{Cooling by comfort ventilation}

a. Cross ventilation: natural ventilation is enhanced when the inlet and outlet are placed at the diagonal of the indoor space, for both plan and section. Key considerations include: building orientation toward the prevailing wind direction, size of the inlet and outlet opening and depth of the space:

b- Stack ventilation: when hot air rises, it creates a natural draft, removing the heat in a building. Key considerations include: height of the stack, areas of the inlet and the stack outlet, material and color of the stack, unobstructed wind flowone of the architectural elements to capture prevailing wind is wind catcher. Fig. 4B.

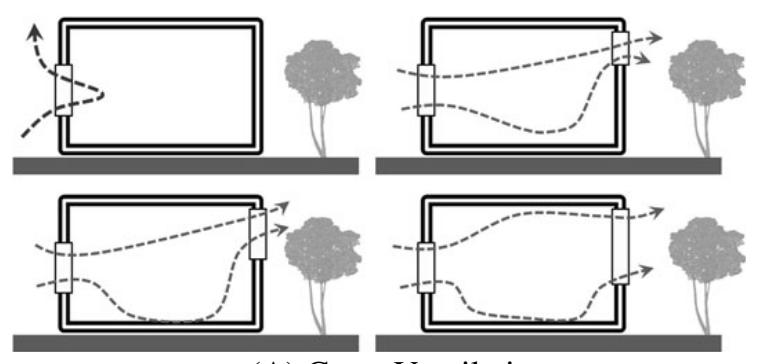

(A) Cross Ventilation

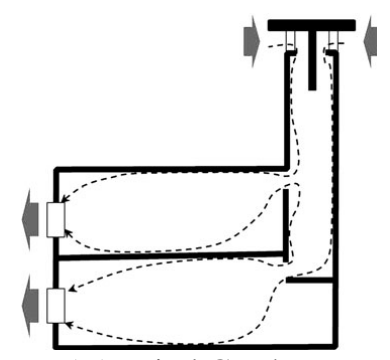

(B) Wind Catcher

Fig. 4. Cooling By Ventilation

\subsubsection{Cooling by direct $\&$ indirect evaporative systems}

One of the most suitable techniques in dry hot desert areas is Evaporative method. One way of doing this is to bring the outdoor air into the building through a moist filter or pad. Passive cooling methods with earth tubes and/or cool towers use the same principles but utilize natural systems for air driver and distribution Fig 5A.

Hybrid techniques proven to be effective in evaporative cooling technique in hot arid areas.

Integration of evaporative cooling technique with solar chimney to improve indoor thermal environment was examined in the New Assiut City, Egypt see Fig. 5B.

The results show that the integrated system interacts with the building envelope and weather conditions to achieve a decrease in indoor temperatures that reach $10^{\circ} \mathrm{C}$ to $11.5^{\circ} \mathrm{C}$ compared to outdoor temperatures. 


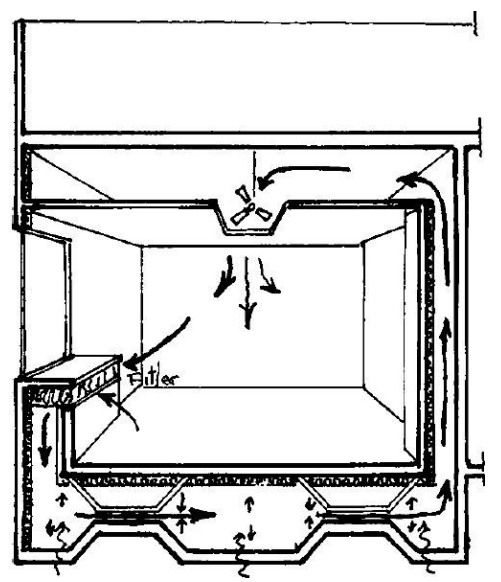

(A)a hybrid smart system

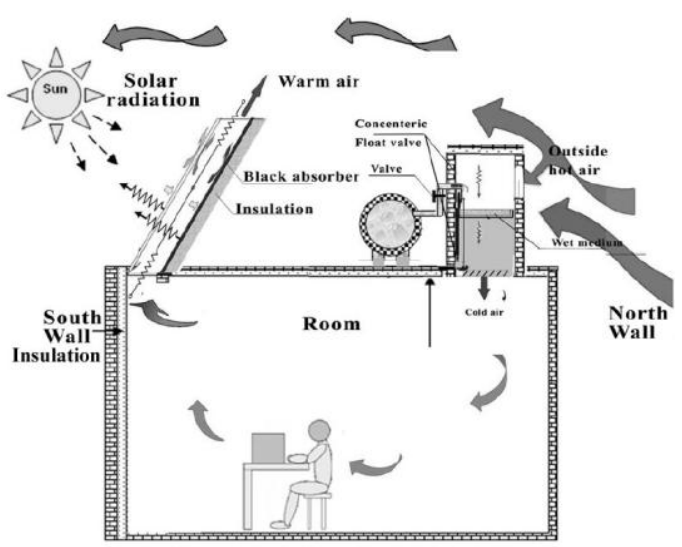

(B) solar chimney with evaporative cooler wind tower

Fig. 5. Cooling By Direct \& Indirect Evaporative Systems

\subsubsection{Cooling by thermal earth inertia}

Passive cooling system could be obtained by making an underground chamber which stores cool air. Passive or hybrid cooling system employs the natural cooling techniques for sustainable building design, from extreme climates.

\section{a- Underground Building}

The contact of external building elements with a mass of soil is another form of thermal buffering. Soil temperatures are warmer than the outdoor air in winter and cooler in summer. On slopping sites, cutting into the incline can help to reduce envelope exposure as well as shield buildings from the wind and improve solar access between buildings. The underground building is an extreme case of this method. Underground homes in Siwa oasis Fig. 6A, B, C.

\section{b- Cooling by Underground Earth Tubes see Fig. 6D.}

Cooling tubes are long, underground metal or plastic pipes through which air is drawn. The idea is that as the air travels through the pipes, it gives up some of its heat to the surrounding soil, entering the building as cooler air. This will occur only if the earth is at least several degrees cooler than the incoming air [13].

A hybrid technique using ground-source heat pumps can offer energy cost savings relative to more conventional heating and cooling strategies (air-cooled chillers, air conditioners, boilers, etc.). Geothermal heat pump systems, also known as "geoexchange," are the most energy efficient, environmentally clean, and cost-effective space conditioning systems available, according to the Environmental Protection Agency.

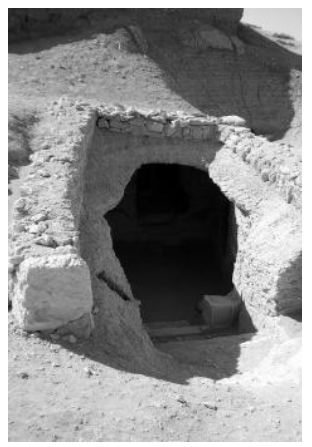

(A) Home entrance

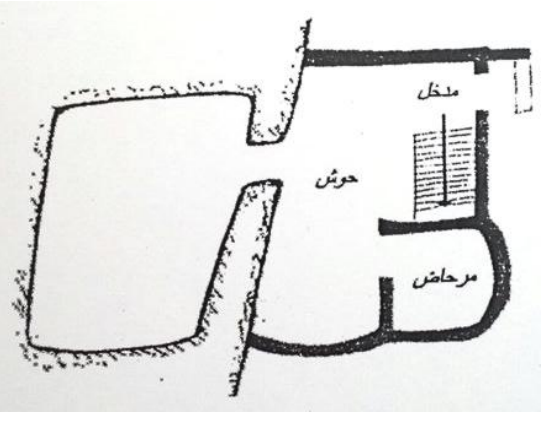

(B) One of the partially buried homes

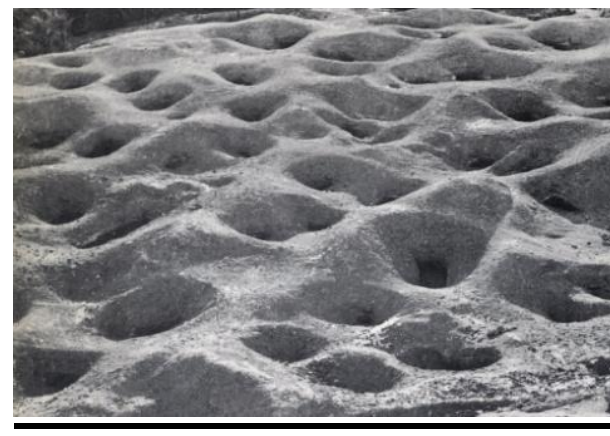

(C) Organic Aggregation 


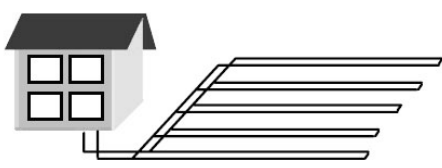

(a)

Horizontal type

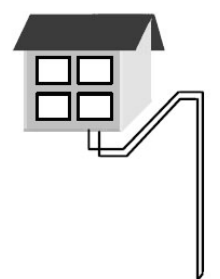

(b) Vertical type

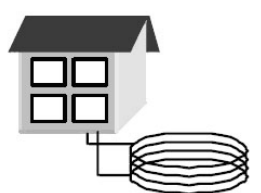

(c) Innovative exchanger using no-dig method

(D) Concept of underground heat exchangers

Fig.6 . Cooling By Thermal Earth Inertia

\subsubsection{Landscape}

Studies conducted by Lawrence Berkeley National Laboratory found summer daytime air temperatures to be $3^{\circ}$ to $6^{\circ} \mathrm{F}$ cooler in tree-shaded neighborhoods than in treeless areas. That could be a 9 to $20 \%$ savings in cooling costs.

\section{Xeriscaping}

A Water-Wise Landscaping that conserves water. Initiated by the Denver, Colorado Water Dept. The Seven Principles of Xeriscaping are [10]:

- First Principle: Planning a design, Plants need to by hydro zoned(Grouped according to water needs).

- Second Principle: Soil analysis, Existing Structures, Nutrient Content, Water Retention Capacity, Drainage Characteristics.

- Third Principle: Appropriate plant selection, Plants should be chosen for their suitability and adaptability to the site.

- Fourth Principle: Practical Turf Areas, Turf areas are the greatest users of water in the landscape. Grass should only be used where it is functional

- Fifth Principle: Efficient Irrigation, Encourage roots to grow deep. Micro-irrigation systems. Water should be applied early in the day.

- Sixth Principle: Mulching, Mulch provides a cover for soil, keeping it moist and preventing evaporation. Water retention. Organic mulch. Thickness of 4" or better

- Seventh Principle: Appropriate Maintenance, Sweeping walks after watering. Mowing turf areas to reduce excessive growth. Rain Barrels

\subsection{Low cost and local low embodied energy materials}

Sustainable materials are keys to limiting the impact on the ecological system. Depending on the type of the material, it can reduce the flow, storage and release of heat. In warm, hot climates the thermal resistance, reflection, absorption and emissivity coefficients are important factors, to reduce the energy demand for cooling.

Wallbaum, H. et al. (2012) produced Indicator based sustainability assessment tool for affordable housing construction technologies. The paper screened about 75 construction technologies and assessed 46 of them. The main finding was that the most promising technologies are closely connected to local production of materials [9].

Under the proposed set of indicators and weighting factors, the most strongly performing technologies are those associated with using hybrid materials of both bio-based products (such as bamboo and timber) and industrialized products (such as synthetic materials). Morela ( 2001) [5].

Vernacular architecture in the Western Desert is rich in examples of different approaches to earth building technology. Mainly, the building method for walls is mud bricks while exceptionally in the Siwa oasis it is salt blocks and mud (Karshif blocks). Along with the earth, the main roof material is local wood, either from trees or palms. Reeds and palm ribs are used as secondary construction materials in roof construction. Earth is an extremely versatile substance. It can be combined with many other components or materials, especially straw and natural fibers, to form solid volumes, thick walls and unifying plaster [6]. Building with earth is an easy yet labor intensive process, a fact that can be considered an advantage in developing countries [7].

Using stabilized earth improves its thermal properties and reduces the energy consumed for heating and cooling which is negligible when compared to conventional methods using concrete and fired brick [8]. 


\section{INTERNATIONAL EXPERIMENTS}

Energy efficient low cost practices which comprise three major aspects:

a. Construction materials and methods. b. Design aspects. c. Renewable energy technologies.

The following part of this paper will present six international experiences of low cost housing projects all over the world comprising the mentioned aspects.

\subsection{Earth Ships Biotecture}

Location: Taos, New Mexico.

Architect: Mike Reynolds

Area: 100m2 floor area not including the greenhouse (an extra 60m2).

Climate Data: altitude of 7,000 feet, and with temperatures ranging between $37^{\circ} \mathrm{C}$ and $-30^{\circ} \mathrm{C}$.

Date: The dwellings became a legal subdivision in 1998.

Earthship is an autonomous home which utilizes passive solar principles, earth-sheltered design and innovative "offgrid" systems to provide the occupants with shelter, thermal comfort, food, water, electricity and wastewater treatment Fig. 10A.

\section{a. Construction materials and methods}

In this model the exterior wall construction is made from tires filled with rammed earth (Fig. 10B). A layer of polystyrene is positioned vertically in the berm about $1200 \mathrm{~mm}$ from the tyires. glass bottles made into walls using cement for bonding. The roof is corrugated metal with a propanel finish, so clean water can be collected from its surface

\section{b. Design aspects}

Orienting the building to south to gain the most heat in winter to the front gallery (see Fig.10C) which is intended as an infrequently used space (it serves as an air-lock entry/corridor) [17]. So Ventilation is from the front gallery .Roof window for hot air to exit in summer.

Front south glass elevation provides natural lighting with the help of light tubes.

\section{c. Renewable energy technologies}

Water is heated from the sun, biodiesel and/or natural gas is used in all earthship models. In addition, using PVs \& Wind catchers.

Hourly monitoring data of the indoor temperature were used to calibrate a simulation model of the building the results show that the Global Earthship is able to provide thermal comfort without heating and cooling provided there is adequate solar irradiance but where overcast conditions prevail, a small amount of backup heating is necessary See Fig. 10D,E.

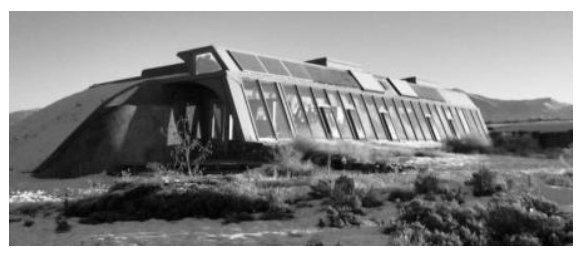

(A) View of Earth ships Biotecture

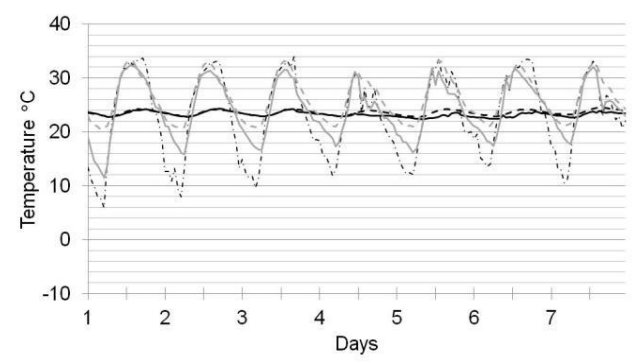

-... Meas Out T —Meas Int T - - Sim Int T — Meas GH T - - Sim GH T

(D) Taos 25 Jun - 1 Jul 2012

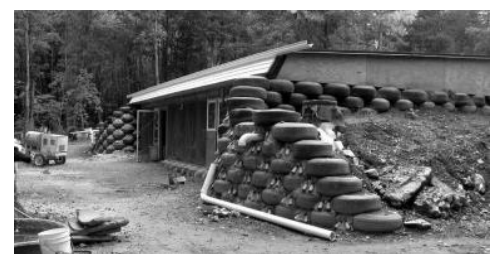

(B) exterior wall from tyres filled with rammed earth

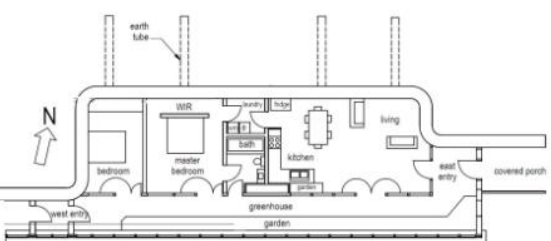

(C) Earthship plan

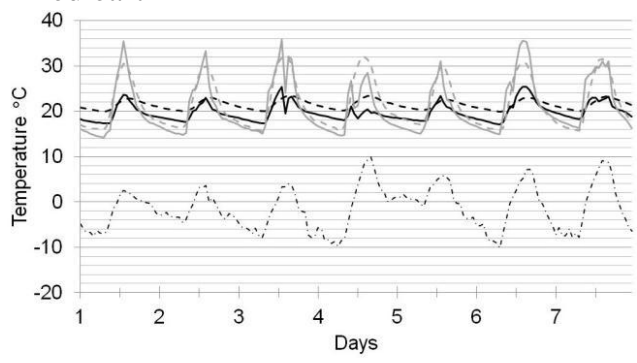

-..-Meas Out T - Meas Int T - - Sim Int T - Meas GH T - - Sim GH T

(E) Taos 5-11 Feb2012

Fig. 10. Earth Ships Biotecture 


\subsection{A low cost, single-family, sustainable house prototype (Alvorada House)}

Location: Porto Alegre, Brazil

Architect: interdisciplinary team at Engineering College of the Rio Grande do Sul University

Area: $48 \mathrm{~m} 2$.

Climate Data: annual average air temperature in the city is $19.58 \mathrm{C}$, with historical extremes of $39.88 \mathrm{C}$ and $0.78 \mathrm{C}$.

Date: 2003.

The prototype, called Alvorada House, is located in the city of Porto Alegre (308S; $518 \mathrm{~W})$, was built on the university campus, several sustainable issues were considered in the design phase.

\section{a. Construction materials and methods}

The walls were built mostly with $0.11 \mathrm{~m}$ ceramic clay bricks, except for the southern and western external walls where thermal insulation. Recycled aluminum for roof insulation (reused printing offset sheets). With the possibility of self-construction.

\section{b. Design aspects}

Solar orientation; the most frequently used areas are oriented to the North or East. Vegetation for shading the house and the construction of a pergola, with creepers, built to shade and protect the West facade from direct solar radiation, and an operable opening in the roof for summer ventilation of its attic, see Fig. 11A

\section{c. Renewable energy technologies}

\section{Solar collector for water heating}

Thermal performance of the house was monitored, by recording Outdoor and indoor air temperature and relative humidity were recorded, see Fig.11B. On an hourly basis, over a whole year. Findings demonstrate that simple bioclimatic strategies, such as those adopted in the Alvorada prototype, can significantly improve the thermal performance of low-cost housing [18].

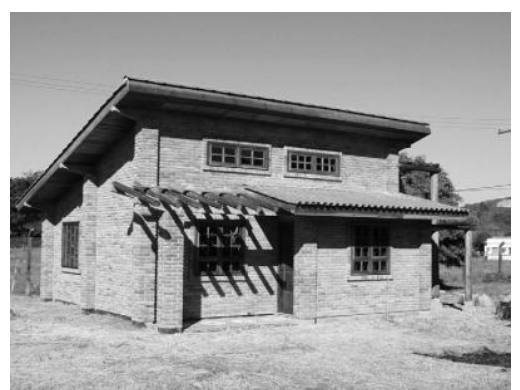

(A) View of the Alvorada House prototype.

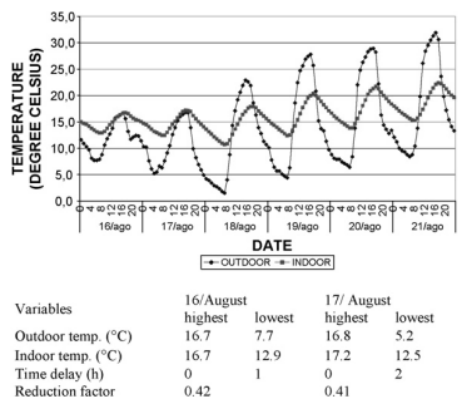

(B) Outdoor and indoor air temperature, time delay and reduction factor for a hot spell.

Fig.11. A Low Cost, Single-Family, More Sustainable House In Porto Alegre, Brazil

\subsection{The Tijuana Low Cost Sustainable House}

Location: Tijuana, Mexico.

Architect: by faculty and students of Cal Poly Pomona.

Area: First fase: $30 \mathrm{~m} 2$

Climate Data: Temperate, without extreme winters or summers. Maximum average summer and winter temperatures are $30.3 C$ and $22.7 C$ and minimum average summer and winter temperatures are $18.4 C$ and 5 C. Relative humidity is between 50 and $65 \%$.

Date: 2006.

Estimated house cost: $1500 \$$.

The project evolves from an "L" form to a "U" shaped building that maximizes surface to the south (see Fig. 12A, B),

\section{a. Construction materials and methods}

Three gabion walls that can be adjusted help to regulate the topography as shown in Fig. $12 \mathrm{C}$. Prior to the construction of the building, grading, and Reinforced tire foundations gabion retaining wall construction, drainage 
swales and earth bag walls can be constructed by the community. This requires very little outside resources, because much of the materials come from the site itself.

One of the proposed technologies for this project is Papercrete which is comprised of waste paper and cement. The material can be easily formed into blocks and used for the construction of walls and roofs Thus; a 10-12 inch thick wall can be expected to have a high insulating R-30 performance. The strongest mixes exceeded 2000 psi, which would be adequate for load bearing structures of at least two stories with 12 inch wall thickness. This system works better in hot and dry climates. Finally using recycled wood pallet roof truss system.

\section{b. Design aspects}

North south orientation while permitting cross ventilation through the spaces as needed. Materials with high thermal capacity are used to store heat in the winter or act as heat sinks in the summer. Concrete floors and earth bag walls provide the mass needed for thermal storage [19]. "Extensive" green roof of "cal earth" bags (rice sack) has been incorporated into the design to assist in mitigation of rainfall runoff while providing improved heating and cooling performance and an increased roof life expectancy due to reduced UV exposure.

A small water circulation pump moved water through the thermal collector and the floor -through low cost irrigation tubes- to transfer the heat absorbed by the sun's energy in the collector to the slab, which would then radiate into the space to achieve thermal comfort in cold winter times. This is called Solar Radiant Floor Heating System [20].

\section{c. Renewable energy technologies}

Solar air heaters in the south walls and hydronic systems with solar collectors to heat the water.

Thermal simulations with energy modeling software indicate that passive heating and cooling systems provide thermal comfort inside the house.

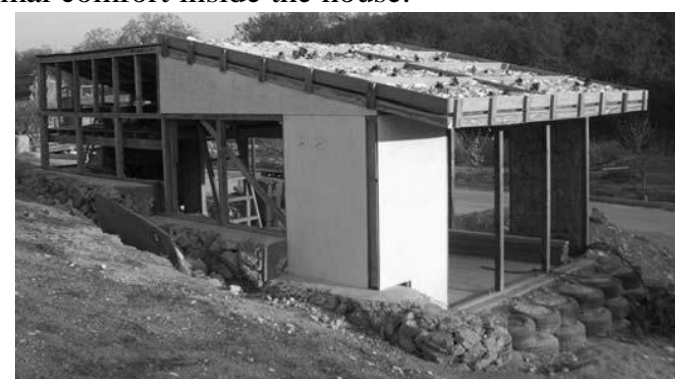

(A) View of the House

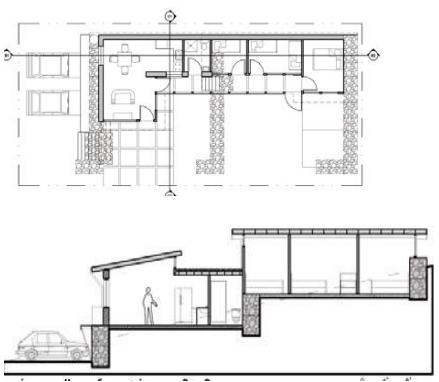

(B) Plan and Section of fase 2

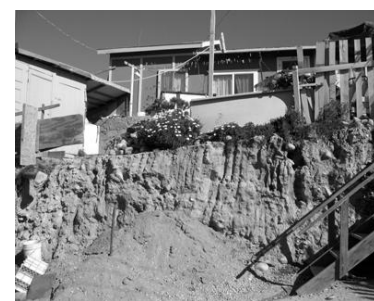

(C) severely degraded natural environment

Fig. 12. The Tijuana Low Cost Sustainable House

\subsection{An experimental Low cost Desert House in Mexico [21].}

Location: Hermosillo, Mexico.

Area: $33.5 \mathrm{~m} 2$ and $39 \mathrm{~m} 2$

Climate Data: hot and dry, characterized by very high levels of solar radiation. Summer daily temperatures between $25-30^{\circ} \mathrm{C}$ and $40-45^{\circ} \mathrm{C}$. Winter daily minimum temperatures of 4 to $7^{\circ} \mathrm{C}$ and maximum temperatures of 25 to $30^{\circ} \mathrm{C}$. Relative humidity is very low during nearly the entire year

Date: 2005.

A test House has been constructed on a university of Sonora campus Fig.13A. Design strategies have been based on the local desert climate:

a. Construction materials and methods.

Walls: compacted earth block.

\section{b. Design aspects.}

Minimizing heat gains with an adequate orientation, providing solar protection devices, minimizing conduction gains, providing thermal inertia, and allowing nocturnal heat loss.

East and west façades are detached, All openings (doors and windows) are protected by vertical or horizontal solar shading devices A roofing system built of a high thermal mass material in the interior layer and a thermal insulation material on the exterior layer, covered by a high-reflectance film finished with a layer of white elastomeric insulation as a reflective and waterproofing material, reinforced with a textile membrane. 


\section{c. Renewable energy technologies.}

Solar water heater was used and a 1-kW network-connected photovoltaic system.

To describe the house performance, indoor air temperature measurements were compared with temperature comfort limits. And the applied thermal strategies are demonstrated to be effective. See Fig. 13B.

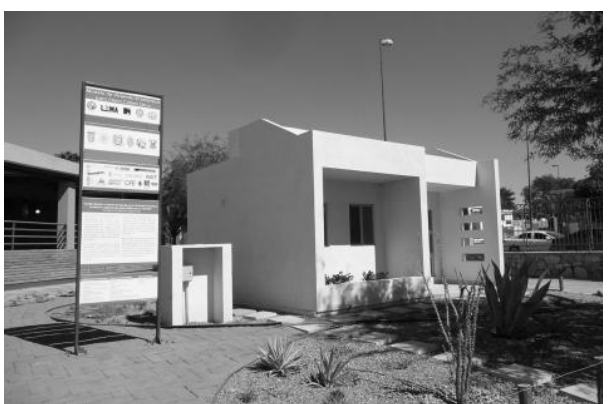

(A) View of the House

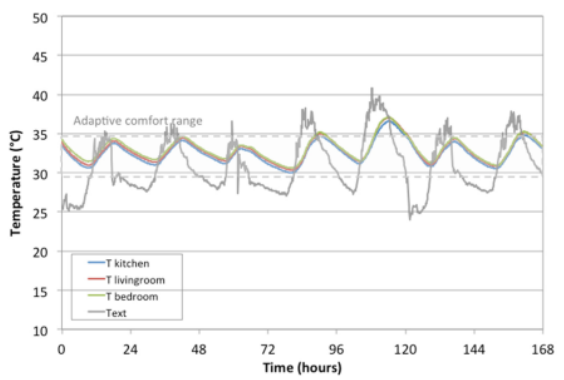

(B) Indoor and external airT. during a summer week

Fig. 13. Experimental Low Cost Desert House In Mexico

\subsection{Sustainable Urban Dwelling Unit (SUDU). Fig. 14A.}

Location: Durame (Kambaata Region) in Ethiopia

Climate Data: Average temperature of $15^{\circ} \mathrm{C}$ and an average annual rainfall of $1250 \mathrm{~mm}$

Date: 2010

Estimated house cost: $6449 \$$.

A two story residence house intended to work as a demonstration building for the population in Ethiopia. Construction element Description as follows:

\section{a. Construction materials and methods.}

Foundation: Reinforced concrete slab

Flooring: Screed wood

Windows and doors: Timber

Roofing Ring beam, vault constructed with $8 \%$ cement clay tiles. See Fig.14B.

Walls: First floor with Rammed earth and Second floor with Interlocking cement stabilized soil blocks as in Fig. 14C. (A CSSB is a building block made from soil, water and cement; working as a stabilizer, mixed and compressed in a pressing machine).

\section{b. Renewable energy technologies.}

And biogas systems were implemented.

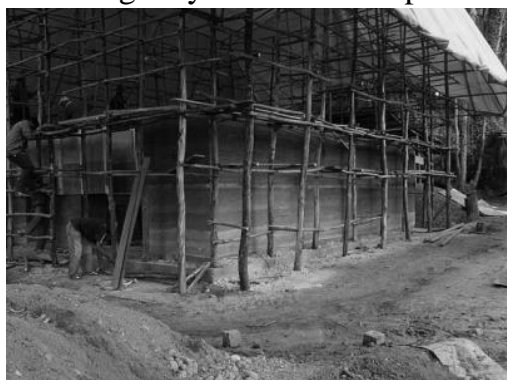

(A) sustainable urban dwelling unit (sudu), Ethiopia

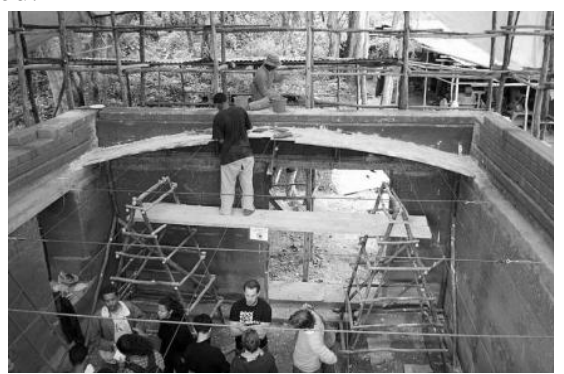

(B) The construction of the 1 st floor vault is under process

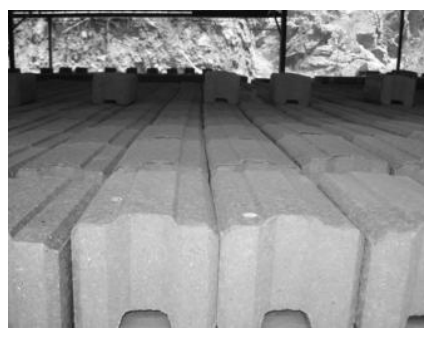

(C) Interlocking CSSB

Fig. 14. Sustainable Urban Dwelling Unit (SUDU) in Ethiopia

\subsection{A low cost 30 apartment block}

Location: Madrid.

Climate Data: hot and dry during the summer and cool during winter period. Daily thermal amplitude is high, more than 15.8C in summer Date: 2006. 


\section{a. Construction materials and methods.}

Chimneys are constructed from prefabricated low cost SHUNT.

\section{b. Design aspects.}

Longitudinal axis in a north-south orientation. East and West Facades are designed to achieve max solar protection as in Fig.15A. Day ventilation in summer is provided with pre-cooled outside air by circulating through the sanitary area of the building located $6 \mathrm{~m}$ below grade. Two chimneys connected through the living room of each apartment. The chimney (left line) connects the sanitary area of the building with the low part of the living room and the right one connects the upper part of the living room of each apartment with the solar chimney located on the roof of the building (described in Fig. 15B,C.)[22].

\section{c. Renewable energy technologies.}

The implemented heating system is a central heating floor panel heating with natural gas central boiler. For domestic hot water (DHW), a solar system consisting of 30 flat plate collectors located at the roof, provides $75 \%$ of the sanitary water energy demand.

To calculate the energy consumption of the building, the Visual DOE 4.0 energy analysis tool has been used. Simulation results from Building Energy Performance Summary Report shows that the total site energy using the energy index is $45.6 \mathrm{kWh} / \mathrm{m} 2$ per year per net area. Reference values for new building in Madrid are more than 80 $\mathrm{kWh} / \mathrm{m} 2$ per year. See Fig. 15D.

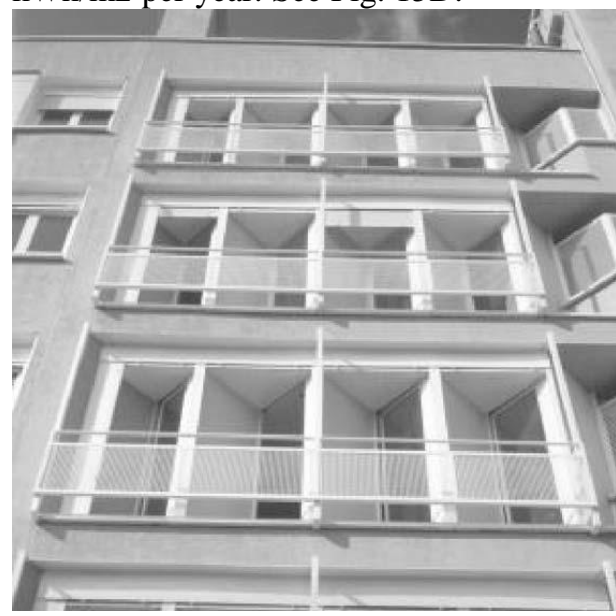

(A) Design of the east and west facade windows

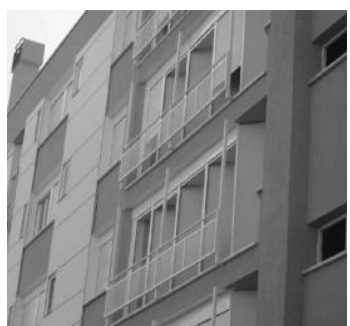

(B)Solar chimney

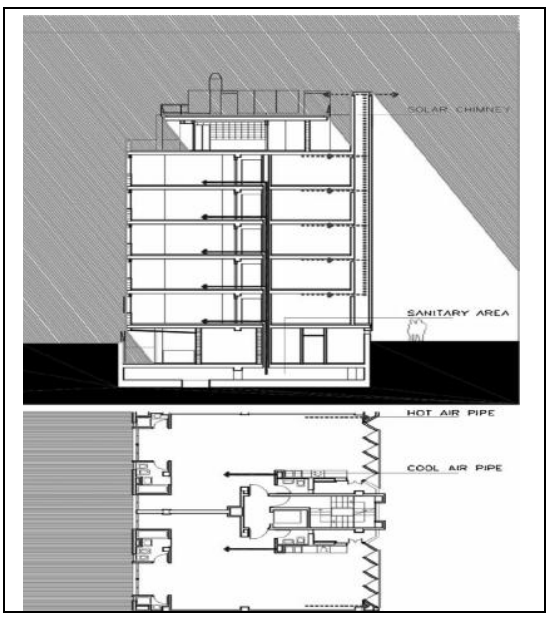

(C) Design of the natural ventilation system.

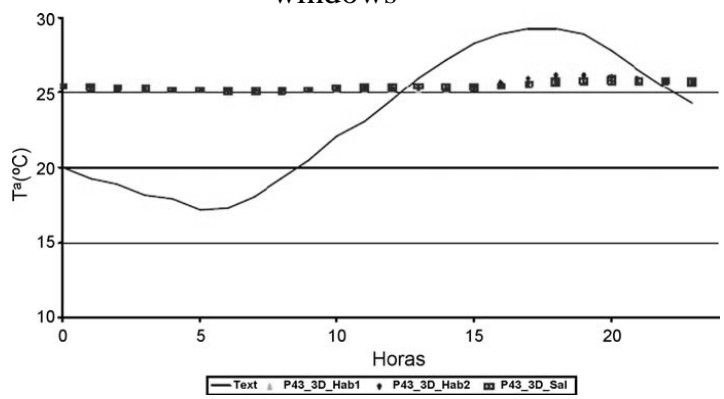

.(D) Room temperatures for a typical summer day

\section{REVIEW FINDINGS}

Fig. 15. A low cost 30 apartment block

The research found that each of the studied projects fulfilled one or more of energy efficient low cost practices comprise three major aspects: 


\subsection{Construction materials and methods:}

Most Low cost sustainable projects used in site local \& recycled materials with local intensive labor construction methods such as: reinforced with earth recycled Car tires and rocks, straw bale, Paper Crete, Glass bottles and metallic cans, Earth bags, Earth / Cement Stabilized Soil, and for roofs: recycled pallet wood to construct structural trusses, Recycled aluminum for roof insulation and recycled corrugated sheets, Ring beam, vault constructed with 8 $\%$ cement clay tiles.

\subsection{Design aspects}

Passive and hybrid techniques are key stones for any sustainable low cost design. Most of the presented projects paid attention to Thermal \& luminous comfort considerations although none of the projects pay attention to acoustical treatments. North south on inward court yard orientation, roof window for hot air to exit in summer, simple radiant floor heating system, wind catchers, solar chimneys, earth sheltered homes, cooling by underground tubes and extensive" green roofs are the most implemented techniques in studied energy efficient low cost projects.

The followings are suitable passive design measures for walls and windows to reduce the cooling thermal energy demand and improve thermal comfort [4]:

Package of Measures I: that can bring about 15\%-20\% reduction in cooling thermal energy demand: Use of light colors on wall (absorptivity $\leq 0.4$ ) + window shades with extended overhangs to intercept direct solar radiation on the window + insulated walls (U-value: $0.7 \mathrm{~W} / \mathrm{m} 2 . \mathrm{K}$ ) + optimized natural ventilation.

Package of Measures II: that can bring about 40\%-45\% reduction in cooling thermal energy demand: Package of Measures I + external movable shutters on windows.

Package of Measures III: that can bring about 50\%-60\% reduction in cooling thermal energy: Package of Measures II + improved wall insulation (U-value: $0.5 \mathrm{~W} / \mathrm{m} 2 . \mathrm{K}$ ) + use of double glazing in windows + better envelope airtightness.

\subsection{Renewable energy technologies}

Some of the projects used appropriate techniques including solar collectors, biodiesel / natural gas, photovoltaic, micro Wind catchers \& Bio Gas system.

\section{CONCLUSION}

The paper explored the constrains and the energy efficiency strategies for hot arid zones then it reviewed passive \& hybrid design techniques then screened six case studies of energy efficient low cost housing projects worldwide showing their energy efficiency practice and their methods to overcome climate and cost challenges using hybrid and passive techniques along with using local materials and renewable energy. The paper recommended some of these techniques to be implemented in Egypt as shown in table 3:

Table 3. Recommended Hybrid and Passive Techniques

\begin{tabular}{|c|c|c|c|c|}
\hline & & & \\
\hline \multicolumn{2}{|c|}{$\begin{array}{l}\text { Energy Efficient Aspects } \\
\text { Construction materials } \\
\text { and methods }\end{array}$} & & & \\
\hline \multicolumn{2}{|c|}{$\begin{array}{l}\text { Renewable energy } \\
\text { Lighting \& Equipment }\end{array}$} & \multirow{3}{*}{$\begin{array}{l}\text { Techniques } \\
\begin{array}{l}\text { Using in site local \& } \\
\text { recycled materials }\end{array} \\
\\
\\
\\
\\
\\
\\
\begin{array}{lr}\text { Using } \\
\text { efficient } \\
\text { systems }\end{array} \\
\text { Xeriscaping }\end{array}$} & \multirow{3}{*}{$\begin{array}{l}\text { Advisable Treatment } \\
\text { Foundations \& retaining: recycled car } \\
\text { tires reinforced with earth. } \\
\text { Free standing walls: Paper Crete\& } \\
\text { straw bale } \\
\text { Bearing walls: Compressed Stabilized } \\
\text { Earth Block(CSEB)\& Rammed Earth } \\
\text { techniques } \\
\text { Roofs: recycled pallet wood \& ring } \\
\text { beam, vault \& domes with earth blocks } \\
\text { \& clay tiles } \\
\text { Installing solar water heaters } \\
\text { Using LED technologies for lighting } \\
\text { and energy efficient labeled equipment } \\
\text { The proposed Xeriscaping techniques } \\
\text { is essential in desert using simple } \\
\text { mechanical low cost irrigation } \\
\text { techniques }\end{array}$} & \multirow{3}{*}{$\begin{array}{l}\text { Type } \\
\text { Passive } \\
\text { \& } \\
\text { Hybrid }\end{array}$} \\
\hline \multicolumn{2}{|c|}{ Lighting \& Equipment } & & & \\
\hline $\begin{array}{l}\text { Sustainable } \\
\text { Design } \\
\text { Aspects }\end{array}$ & & & & \\
\hline
\end{tabular}


PASSIVE AND HYBRID TECHNIQUES FOR LOW COST ENERGY EFFECIENT HOUSING IN HOT DRY CLIMATE

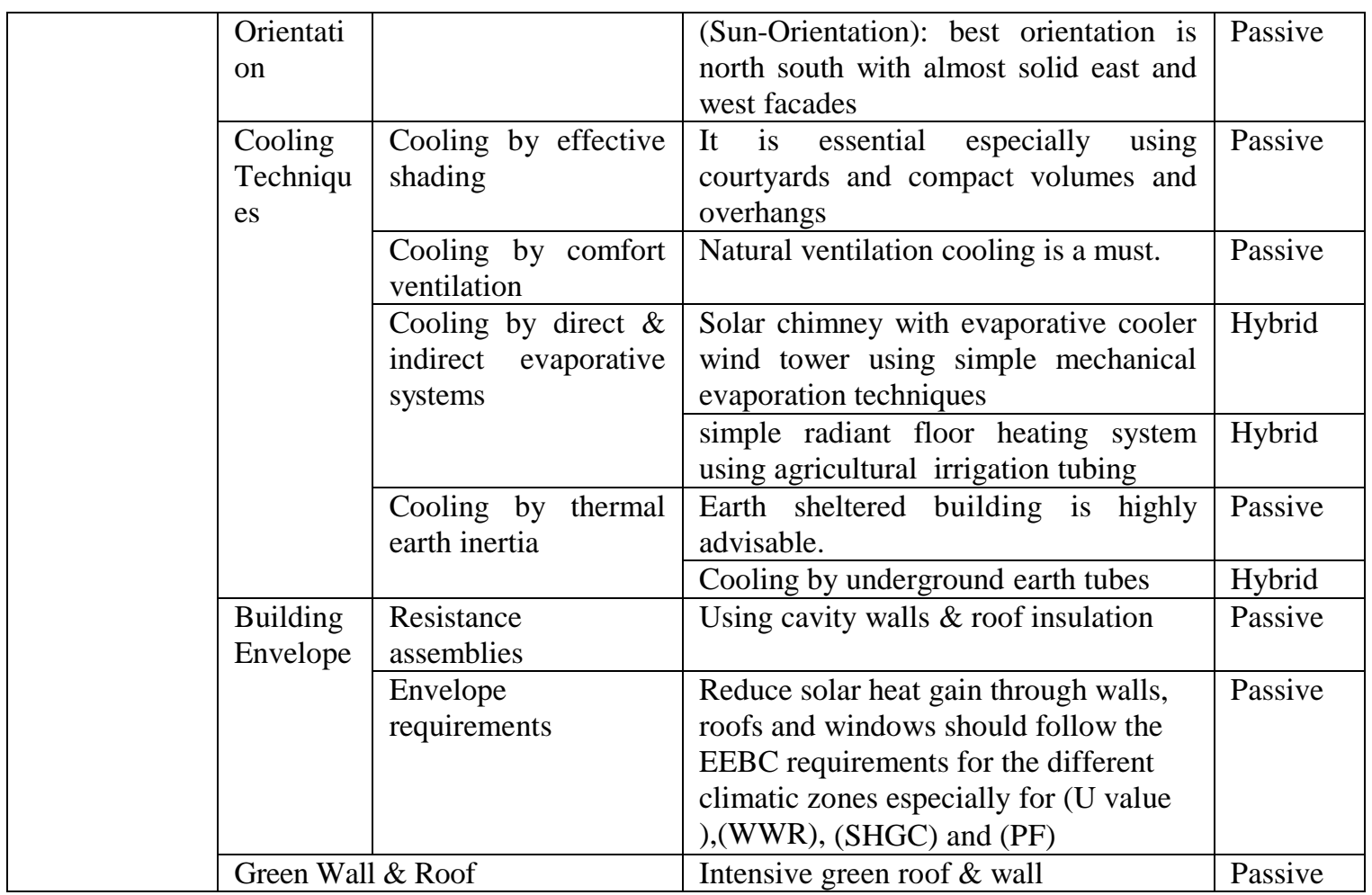

\section{REFERENCES}

1. Mulliner, E. et al. (2013), "An assessment of sustainable housing affordability using a multiple criteria decision making method", Omega, Vol. 41, pp.270-279. (https://energypedia.info/wiki/Egypt_Energy_Situation)

2. Energypedia, (2013), Egypt Energy Situation (https://energypedia.info/wiki/Egypt_Energy_Situation)

3. MED-ENEC, (2013), "Energy efficient Building guideline for MENA region", MED-ENEC. (www.med-enec.eu)

4. Bureau of Energy Efficiency, Government of India, (2014), "Design guidelines for energy efficient multi story residential buildings, India

5. Morela, J.C., Et al., (2001), "Building houses with local materials: means to drastically reduce the environmental impact of construction". Building and Environment, Vol. 36(10), pp. 1119-1126.

6. Luisa.R, et al., (2009), "The salt architecture in Siwa oasis-Egypt". Construction and Building Materials, Vol. 23, pp. 2492-2503.

7. United Nations Centre for Human Settlements. (1986), "Earth construction technology. Manual on production of rammed earth, adobe and compressed soil blocks" II: London: Intermediate Technology

8. Serrano, S., (2012), "Stabilized rammed earth incorporating PCM: Optimization and improvement of thermal properties and Life Cycle Assessment", Energy Procedia, Vol.30, pp.461-470.

9. Wallbaum, H. et al., (2012). "Indicator based sustainability assessment tool for affordable housing construction technologies". Ecological Indicators, Vol. 18, pp.353-364.

10. Hassan,A., (2012), Lectures on sustainable landscaping, Cairo University, Egypt.

11. Givoni B, La Roche, P., (2001), "Radiant cooling systems for developing countries",Accepted for ISES 2001, Adelaide Australia.

12. Cook, J. (ed) (1989), "Passive cooling". MIT Press, Cambridge. USA.

13. The US Department of Energy Office of Energy Efficiency and Renewable (EERE), http://www.eren.doe.gov. (2007).

14. Bauchard, A., (ed) (2012), "AVEI newsletter", Auroville Earth Institute, issue 2, India.

15. El-Kabbany, M.,(2013), "Alternative Building Materials and Components for Affordable Housing in Egypt", Master Thesis at Ain Shams University, Egypt.

16. UNEP, (2013), "Sustainable Solutions for social housing, Sushi, UN-HABITAT. 
17. Freney, M.,et al., (2013), "Thermal comfort of global model Earthship in various European climates". 13th conference of international building performance simulation association, Chambery, France.

18. Grigoletti,G.,et al, (2008), "Analysis of the thermal behavior of a low cost, single-family, more sustainable house in Porto Alegre, Brazil", Energy and buildings, Vol.40, pp. 1961-1971 .

19. La Roche,P.,et al, (2006), "Very Low Cost Sustainable Housing Prototype for Tijuana, Mexico", 23rd Conference on Passive and Low Energy Architecture, Geneva, Switzerland, September 2006.

20. West,M., (2008), "Developing a Low Cost, Sustainable Housing Prototype Using Recycled Waste Materials in Tijuana, Mexico", 25th Conference on Passive and Low Energy Architecture, Dublin, 22nd to 24th October 2008.

21. Marincic, I., et al., (2014), "Passive house for a desert climate", Eco-Architecture, Vol.13.

22. Macias, M. et al., (2009), "Low cost passive cooling system for social housing in dry hot climate", Energy and Buildings, Vol. 41, pp. 915. 